\title{
DEVELOPING ENTREPRENEURIAL MiNdSET IN ENGINEERS
}

\author{
Kshitij Shinghal $^{1}$, Amit Saxena ${ }^{2}$ \\ ${ }^{1}$ Associate Professor, ${ }^{2}$ Assistant Professor, \\ Deptt. of E\& C Engg, Moradabad Institute of Technology, Moradabad, India
}

\begin{abstract}
When the students join a professional course they have a fixed mindset of completing their course and acquiring a job. Especially the students of science and technology background who join engineering course are strongly driven by the factor that they can not run enterprise, and sole purpose of their life is to get a job in a blue chip multinational company. However these budding engineers are the ones who have most innovative ideas which can be converted in to enterprises. However these students lack the entrepreneurial mindset. The biggest myth that is in their minds is that they can not start enterprise, lot of financial assistance is required, they do not have enough resources etc. the present paper aims to explores the scope of developing entrepreneurial mindset in budding engineers.
\end{abstract}

KEYWORDS: Entrepreneurship, Education, entrepreneurial mindset, engineering education.

\section{INTRODUCTION}

Before addressing the issue of developing entrepreneurial mindset let us first understand what we understand by mindset. Mindset is the one point of view, mental attitude or inclination towards a particular thing as per his capabilities or abilities. It is shown by several researchers that mindset or attitude can be changed by proper training and motivation $[1,2]$.

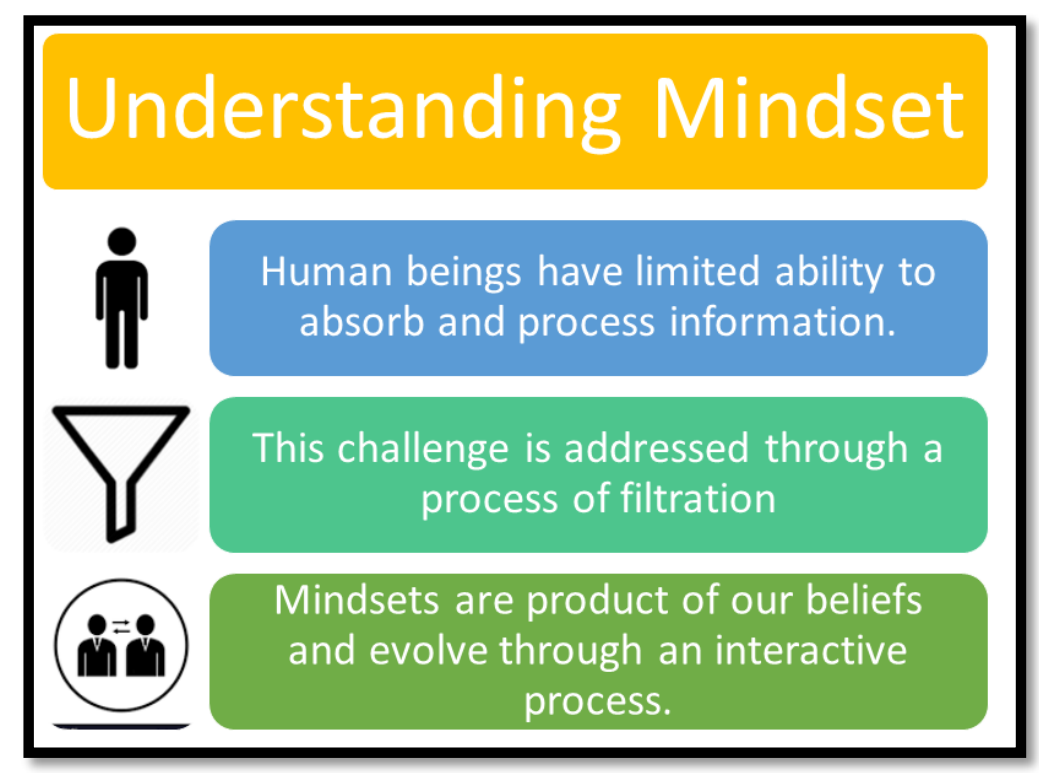

Figure 1: Understanding mindset

Rest of the paper is divided into different sections for the ease of understanding. Section II focuses on developing an entrepreneurship mindset in budding engineers. Section III provides the results and discussion. At the end, conclusion of the work has been given in section VI. 


\section{DEVELOPING AN ENTREPRENEURIAL MiNDSET}

The entrepreneurial mindset is nothing but it as an approach or it is just about a certain way of thinking. It is about the way in which one takes up challenges and learns from his mistakes. It is about an inherent need to inculcate skill set and developing a resilience to try and try again. Five important characteristics of an entrepreneur are given in figure.

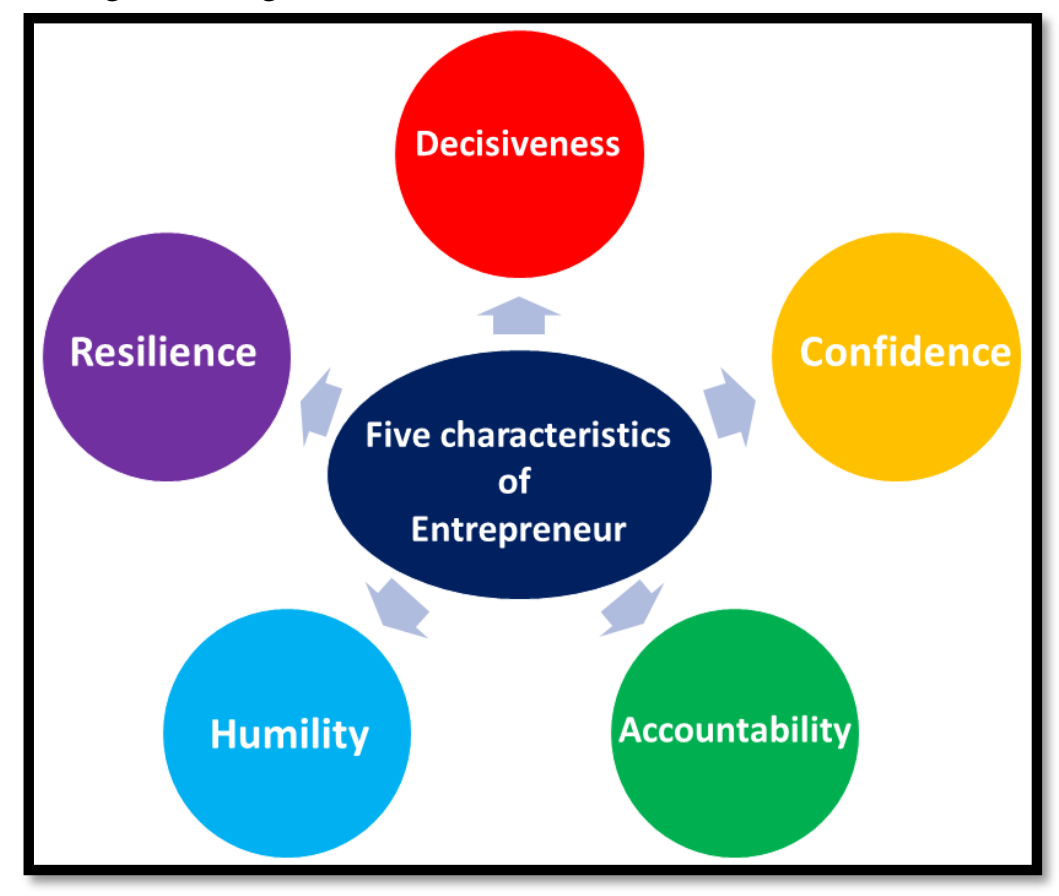

Figure 2: Five important characteristics of an entrepreneur

If the students develop these five characteristics of a successful entrepreneur they are very near to developing an entrepreneurial mindset. The five important spheres of successful entrepreneur are decisiveness as to be a successful entrepreneur, one must gain the ability to look at a problem or situation take judicious decision and move forward with confidence. Second skill set is self confidence, one can achieve what he can believe. There are many skills that a student need to learn to develop entrepreneurial mindset [3-6]. But learning to act confidently is the most important. When one learns to act with confidence he automatically develops the second characteristic of the entrepreneurial mindset. Third important characteristics of successful entrepreneur is accountability, i.e. taking full responsibilities of his actions and outcomes. Fourth skill set is developing resilience as an entrepreneur, one will need to learn to deal with making mistakes and failing. Student has to learn to be persistent and keep on trying, if outcome is not favorable than he may need to reconsider his strategies. Last and most important skill for developing entrepreneurial mindset is humility. Humility is nothing but freedom from pride or arrogance. Humility incorporates all of the characteristics of entrepreneurship. From decisiveness to confidence, it will keep you focused and motivated to achieve your goal. Much of the entrepreneurial mindset involves a steadfast commitment to a really narrow vision. This drive allows entrepreneurs to hold out the required steps to accomplish that vision. That's why it is so important to form an attempt fix aside a selected time every single day to focus upon your vision and your goals to bring your vision to the forefront. The key, however, is to really make this commitment concrete. As an entrepreneur, you'll naturally face new challenges a day. Simply because obstacles arise doesn't suggest you ought to be scared of making mistakes. If you would like to cultivate an entrepreneurial mindset, you've got to embrace challenges. You have to hunt them out. So, by treating tasks as problems to be solved and pondering how you'll provide value at every single turn you'll continually put the entrepreneurial mindset into practice.

Above all, the three important Building Blocks of Entrepreneurship are depicted in figure 3. These are: 
International Journal of Scientific Research and Management Studies (IJSRMS)

ISSN: 2349-3771 doi: 10.7323/ijsrms.2017.v04i02.003

Volume 4 Issue 2, pg: 56-59

1. Identify the opportunity. This usually means finding a problem to be solved or a need to be filled.

2. Create value. Solving the problem or filling the need in a unique way.

3. Capture that value.

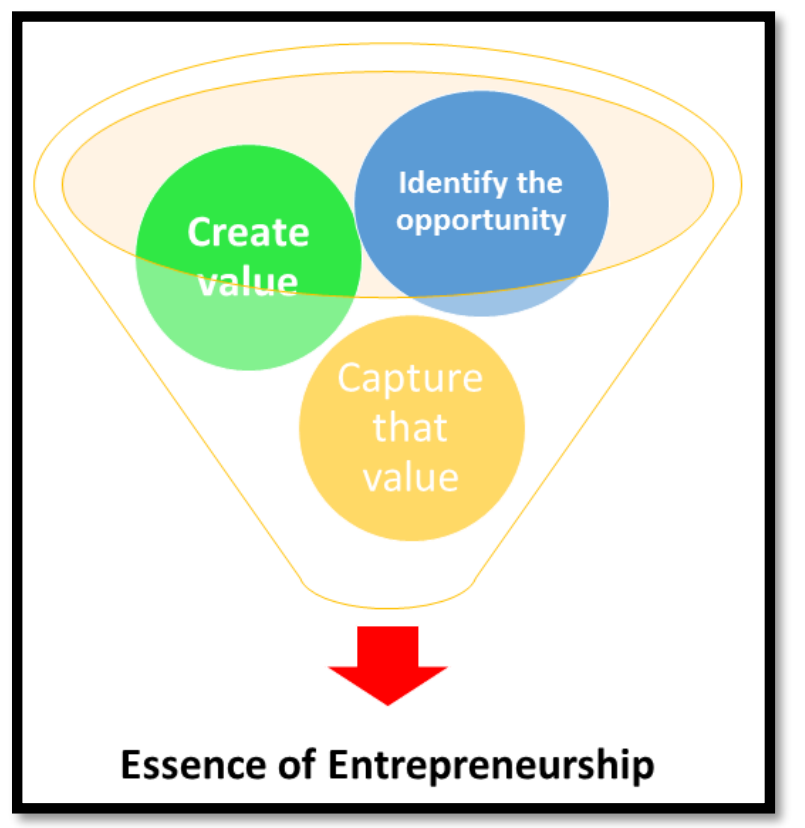

Figure 3: Three important Building Blocks of Entrepreneurship

\section{RESULT AND DISCUSSIONS}

Developing the entrepreneurial mindset is about being committed to your vision no matter the challenges and obstacles along the way. It's about seeing mistakes as a chance for growth and not as something to be feared. It's about approaching problems from a variety of various ways. By embodying all of the above, students can develop their entrepreneurial mindset and equip themselves with one among the foremost important tools that an entrepreneur can have.

\section{CONCLUSION}

This paper provides readers with a base understanding of why the entrepreneurial mindset is vital to engineering students and the way it are often developed. It helps advance entrepreneurship education for all engineering students, and equips educators with model that allow them to develop the entrepreneurial mindset. It is important to have an insight what is entrepreneurial mindset is, and why it is important. This paper also explores the essential characteristics of a successful entrepreneur. Paper effectively attempts to address the challenges in developing an entrepreneurial mindset in engineering students.

\section{ACKNOWLEDGEMENT}

We owe our sincere feelings of gratitude to MIT Group of Institutions, Moradabad. We are also thankful to Director MIT Prof. B.P. Singh \& former Director General Prof. R. Yadav for their support, guidance and suggestions, which helped us a lot to write the paper.

\section{REFERENCES}

[1]. F. Hassan, H. LeBlanc and K. Al-Olimat, "Inculcating an entrepreneurial mindset in engineering education: Project approach," 2013 IEEE Frontiers in Education Conference (FIE), Oklahoma City, OK, 2013, pp. 121-126.

[2]. K. J. Reid and D. M. Ferguson, "Work in progress - Enhancing the entrepreneurial mindset of freshman engineers," 2011 Frontiers in Education Conference (FIE), Rapid City, SD, 2011, pp. F2D-1-F2D-3. 
International Journal of Scientific Research and Management Studies (IJSRMS)

ISSN: 2349-3771 doi: 10.7323/ijsrms.2017.v04i02.003

Volume 4 Issue 2, pg: 56-59

[3]. B. J. Call, W. H. Goodridge and M. Scheaffer, "Entrepreneurial curriculum in an Engineering Technical Communication course: Looking for impact on creativity and mindset," 2016 IEEE Frontiers in Education Conference (FIE), Erie, PA, USA, 2016, pp. 1-5.

[4]. A. Huang-Saad, "Fostering the entrepreneurial mindset in the engineering classroom," 2009 39th IEEE Frontiers in Education Conference, San Antonio, TX, 2009, pp. 1-6.

[5]. N. Tabrizi, "Fostering an Entrepreneurial mindset in "Digital Systems" class through a ProducerCustomer model," 2016 IEEE Frontiers in Education Conference (FIE), Erie, PA, USA, 2016, pp. 1-9.

[6]. Scott Ryan Kirkpatrick, Anneliese Watt, Ashley Bernal, "Developing an Entrepreneurial Mindset in Engineers: An Application of the Three C's (Creativity, Curiosity, and Connections) in a Collaborative Summer Mega-Course", American Society for Engineering Education 123rd Annual, Conference \& Exposition, New Orleans, LA, June 26-29 2016.

\section{AUTHORS BIOGRAPHY}

Kshitij Shinghal has 18 Years of experience in the field of Academic and is actively involved in research \& development activities. He obtained his Doctorate degree from Shobhit University Meerut in 2013, Masters degree (Digital Communication) in 2006 from UPTU, Lucknow. He started his career from MIT, Moradabad. Presently he is working as an Associate Professor, Deptt of E\&C Engg., at MIT Moradabad. He has published number of papers in national journals, conferences and seminars. He has guided two Masters, more than sixty students of B. Tech, and guiding three Ph.D. \& M. Tech. theses. He is an active Member of Various Professional Societies such as ISTE, IACSIT, IAENG etc.

Amit Saxena has 12 Years of experience in the field of Academic. He started his career from MIT, Moradabad. Presently he is working as an Assistant Professor, Deptt of E\&C Engg., at MIT Moradabad. He obtained his Bachelor's degree in Electronics \& Communication Engineering from I.E.T., Rohilkhand University, Bareilly and Masters degree (VLSI Design) in 2009 from UPTU, Lucknow. He has published number of papers in international \& national journals, conferences and seminars.
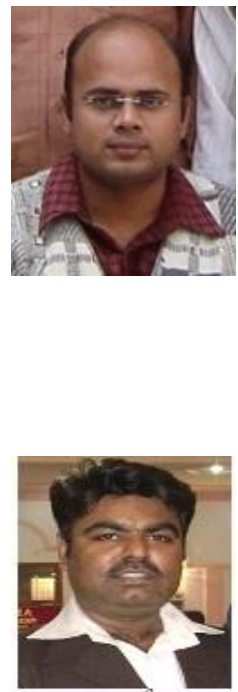